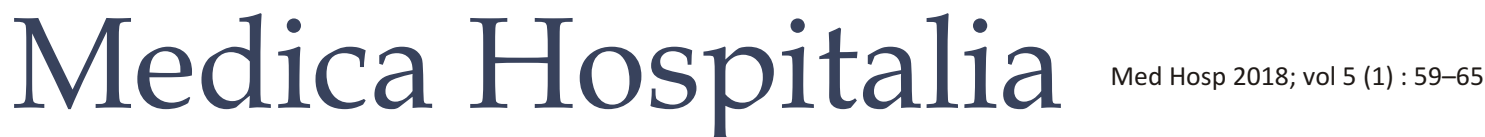

Case Report

\section{Ventricular Septal Rupture Pasca Infark Miokard Akut : Diagnosis Dini dan Tatalaksana}

\author{
Arjatya Pramadita Mangkoesoebroto ${ }^{1}$, Safir Sungkar ${ }^{2}$, Sugiri $^{2}$, Sodiqur Rifqi ${ }^{2}$ \\ ${ }^{1}$ Program Studi Jantung dan Pembuluh Darah, Fakultas Kedokteran, Universitas Diponegoro, Semarang, Indonesia \\ ${ }^{2}$ KSM Jantung dan Pembuluh Darah, RSUP Dr. Kariadi Semarang, Indonesia
}

\begin{abstract}
Abstrak
Latar belakang : Ventricular Septal Rupture (VSR) merupakan komplikasi berat dan langka pada Infark Miokard Akut (IMA) dengan angka mortalitas yang tinggi. VSR menyebabkan pirau kiri ke kanan, memiliki manifestasi klinik dari hemodinamik stabil hingga syok kardiogenik. Pembedahan merupakan terapi definitif, namun masih menjadi tantangan tersendiri karena tingkat mortalitas dan morbiditas yang tinggi.

Laporan Kasus : Seorang laki-laki berusia 59 tahun datang ke Rumah Sakit dengan keluhan sesak napas sejak 3 minggu yang lalu dan didahului nyeri dada khas infark miokard sejak 5 minggu sebelumnya. Terdapat bising pansistolik derajat $3 / 6$, harsh, pada apeks jantung. Elektrokardiogram menunjukan ST segmen elevasi, Q patologis dan T bifasik di lead anterior. Ekokardiografi tampak interventricular septal gap setinggi mid apikal diameter $10 \mathrm{~mm}$ pirau kiri ke kanan, regional wall motion abnormalities, dengan fraksi ejeksi 39\%.Angiografi koroner didapatkan stenosis bermakna di left anterior descending dan right coronary artery. Pasien didiagnosa dengan VSR pasca IMA Elevasi Segmen ST lalu dirawat di ruang intensif untuk stabilisasi hemodinamik, serta direncanakan untuk dilakukan bedah VSR dan Bedah Pintas Arteri Koroner (BPAK).

Pembahasan : Penegakan diagnosis VSR secara dini, terutama pasca IMA bertujuan meningkatkan prognosis jangka panjang.Penutupan VSR merupakan tatalaksana defintif, namun tingkat kematian dini paska bedah yang tinggi merupakan tantangan tersendiri. Penundaan pembedahan VSR dianjurkan untuk meningkatkan stabilitas jaringan miokard. Pada kasus ini dilakukan stabilisasi hemodinamik dan penundaan pembedahan hingga direncanakan pembedahan VSR dan BPAK.

Simpulan : VSR merupakan komplikasi berat dan langka dari IMA, penegakan diagnosis disertai dengan tatalaksana yang tepat dapat mengurangi angka mortalitas dan morbiditas.
\end{abstract}

Kata kunci : ventrikular septal rupture, infark miokard, komplikasi mekanik, bedah jantung

\section{Ventricular septal rupture after acute myocardial infarction : early diagnosis and management}

\begin{abstract}
Background : Ventricular Septal Rupture (VSR) is a rarebut lethal complication of Acute Myocardial Infarction (AMI) with a high mortality rate. VSR causes left to right shunts, has clinical manifestations from stable hemodynamics to cardiogenic shock. Definitive surgery remains the treatment of choice but remains challenging operation associated with high morbidity and mortality.

Case Report : A 59 years old male presented to hospital with complaints of shortness of breath since 3 weeks before admission and preceded chest pain typical of myocardial infarction since the previous 5 weeks. Systolic murmur grade $3 / 6$, harsh was heard on cardiac apex. Electrocardiogram showed elevations of ST segment, pathological $Q$ waves and biphasic $T$ waves in anterior leads. Echocardiography showed an intraventricular septal gap at midapex, $10 \mathrm{~mm}$ diameter, left to right shunt, regional wall motion abnormalities, with an ejection fraction of $39 \%$. Coronary angiography found significant stenosis in the left anterior descending and right coronary artery. Patient was diagnosed with VSR after STEMI then treated intensively for hemodynamic stabilization and planned to do VSR closure with Coronary Artery Bypass Graft (CABG) surgery.

Discussion : Early diagnosis of VSR, especially after AMI aims to improve long-term prognosis. VSR closure surgery is a definitive management, but remains high rates of early mortality. The improved outcome with delayed surgery related to improved stability of cardiac tissue. In this case, hemodynamic stabilization and delay in surgery were carried out until VSR and CABG surgery was planned.

Conclusion : VSR is a serious and rare complication of IMA, establishing a diagnosis accompanied by appropriate management can reduce mortality and morbidity.
\end{abstract}

Keywords : ventricular septal rupture, miocardial infarction, mechanical complication, cardiac surgery 


\section{PENDAHULUAN}

Ventricular Septal Rupture (VSR) merupakan komplikasi mekanik yang langka dan berat dari Infark Miokard Akut (IMA). Pada era pre trombolisis, insidensi VSR sebagai komplikasi IMA adalah 1-2\%,1 lalu pada era revaksularisasi komplikasi VSR semakin langka dan hanya terdapat pada $0,17-0,31 \%$ pasien..$^{2-5}$ Insidensi VSR juga lebih rendah pada pasien yang dilakukan intervensi koroner perkutan (IKP) primer dibanding dengan IKP elektif pada IMA. ${ }^{6}$ Namun, seiring dengan penurunan insidensi, VSR masih tetap memiliki angka mortalitas yang tinggi (41-80\%) dan tidak berubah pada beberapa dekade terakhir., ${ }^{2,3}$ VSR menyebabkan pirau kiri ke kanan, peningkatan tekanan dan volume right ventricle $(\mathrm{RV})$, peningkatan aliran balik vena pulmonalis, dan peningkatan volume jantung kiri. Sesuai dengan ukuran, derajat aliran pirau, disfungsi RV pasien dengan VSR dapat memiliki manifestasi dari hemodinamik yang stabil sampai syok kardiogenik.

Maka dari itu, disusunlah suatu laporan kasus mengenai VSR sebagai komplikasi mekanik dariInfark Miokard Akut Elevasi Segmen ST (IMA-EST)dengan tujuan membahas penegakan diagnosis serta tatalaksana yang optimal pada populasi pasien tersebut.

\section{LAPORAN KASUS}

Seorang laki laki berusia 59 tahun datang ke Rumah Sakit Dr. Kariadi (RSDK) Semarang dengan keluhan sesak napas yang semakin memberat sejak 3 minggu. Sesak napas memberat bila aktifitas lebih ringan dari sehari hari, berkurang dengan istirahat, serta nyeri dada hilang timbul. Lima minggu sebelumnya pasien mengeluh nyeri dada berat khas infark miokard namun pasien tidak berobat.Karena keluhan tidak berkurang pasien berobat di RS Swasta di Semarang dikatakan serangan jantung dan dirawat selama 7 hari.

Satu hari kemudian pasien mengeluh keluhan sesak napas semakin berat saat dan berobat di RSDK. Di ruang gawat darurat pasien sadar, tampak sesak dengan tekanan darah 110/91 $\mathrm{mmHg}$, heart rate $100 \mathrm{x} /$ menit reguler, respiratory rate $30 \mathrm{x} /$ menit, afebris, dengan saturasi oksigen $92 \%$. Pada pemeriksaan fisik didapatkan peningkatan tekanan vena jugularis, bising pansistolik derajat III di apeks jantung yang menjalar ke linea parasternal kiri setinggi spatium intercostae IV. Ronkhi basah halus terdengar di basal paru kanan dan kiri. X-Foto Thoraks didapatkan kardiomegali serta gambaran edema pulmo. Pemeriksaan Elektrokardiografi (EKG) didapatkan sinus takikardia, 100 x/ menit, Right Axis Deviation, Left Atrial Enlargement, ST Elevasi di V2-V5, T Bifasik di V2-V5 serta Q Patologis di V1-V5 (Gambar 1). Terdapat peningkatan biomarker jantung berupa Troponin I $0.095 \mathrm{mcg} / \mathrm{L}$ dan Creatine Kinasi-MB (CKMB) sebesar $30 \mathrm{U} / \mathrm{L}$. Pasien dicurigai didapatkan VSR, sehingga dilakukan pemeriksaan ekokardiografi dengan hasil didapatkan intraventricular septal gap dengan diameter $10 \mathrm{~mm}$ di mid-apeks dengan pirau kiri ke kanan, regional wall motion abnormalities dan fraksi ejeksi ventrikel kiri 39\% (Gambar 2). Berdasarkan anamnesis, pemeriksaan fisik dan penunjang pasien lalu didiagnosis dengan VSR pasca IMA-EST. Tatalaksana awal dilakukan dengan pemberian oksigen nasal kanul 3 liter/menit, Nitrogliserin $50 \mathrm{mcg} /$ menit intravena, dan furosemide $40 \mathrm{mg}$ intravena. Pasien juga diberikan aspilet $80 \mathrm{mg}$, clopidogrel $75 \mathrm{mg}$, ramipril $2,5 \mathrm{mg}$, atorvastatin $40 \mathrm{mg}$, spironolakton $25 \mathrm{mg}$, dan glimepirid

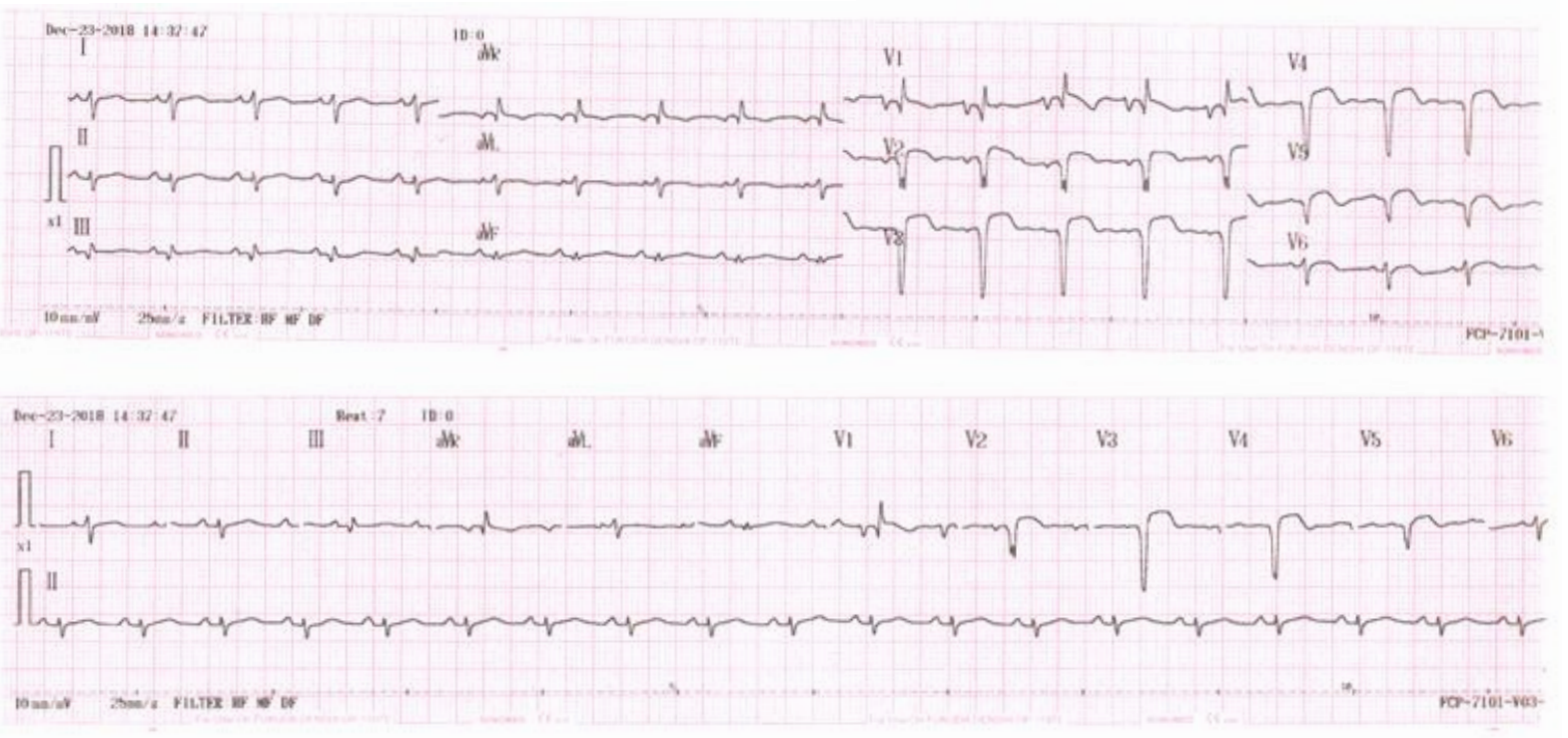

Gambar 1. Q patologis, ST elevasi dan T bifasik di lead anterior menunjukkan recent infark miokard akut elevasi segmen ST 


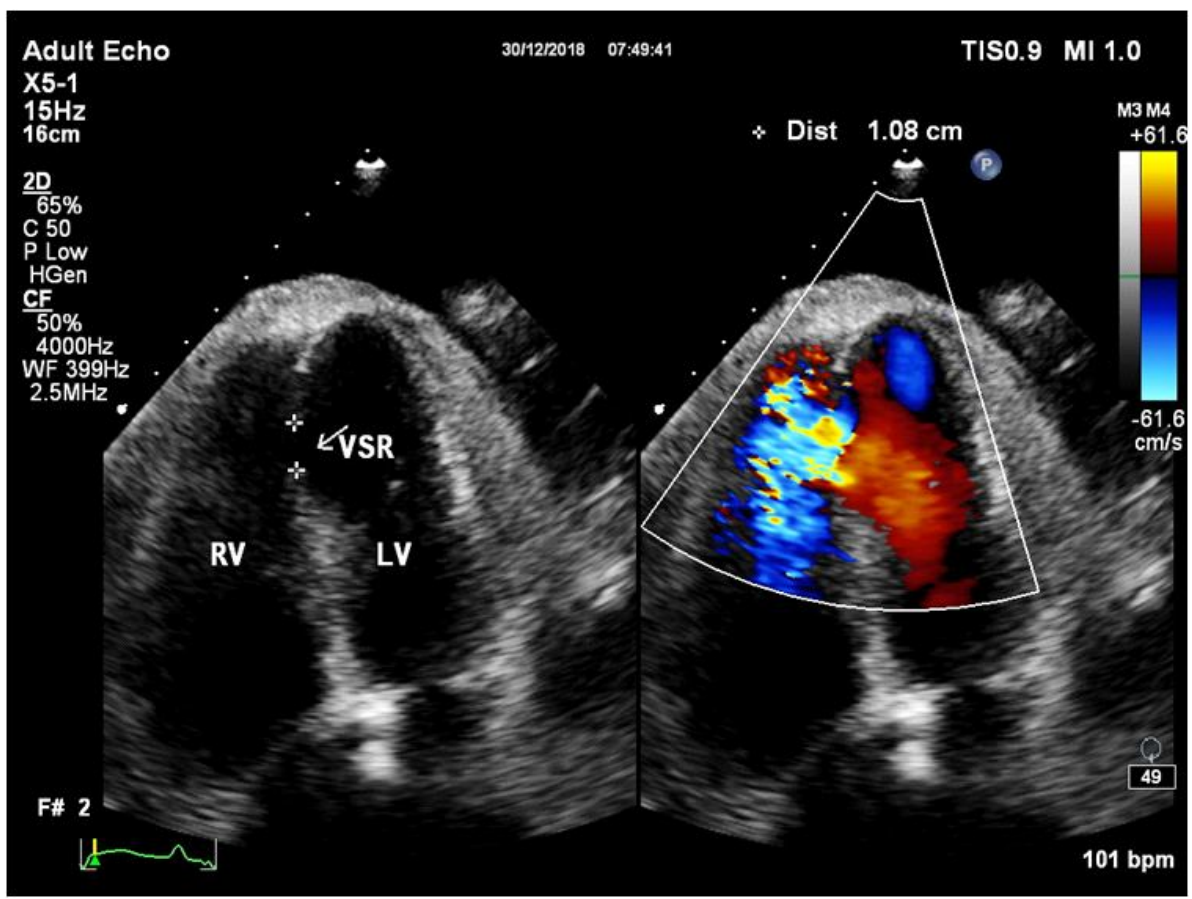

Gambar 2. Gambaran Ekokardiografi Transtorakhal menunjukkan VSR dengan pirau kiri ke kanan
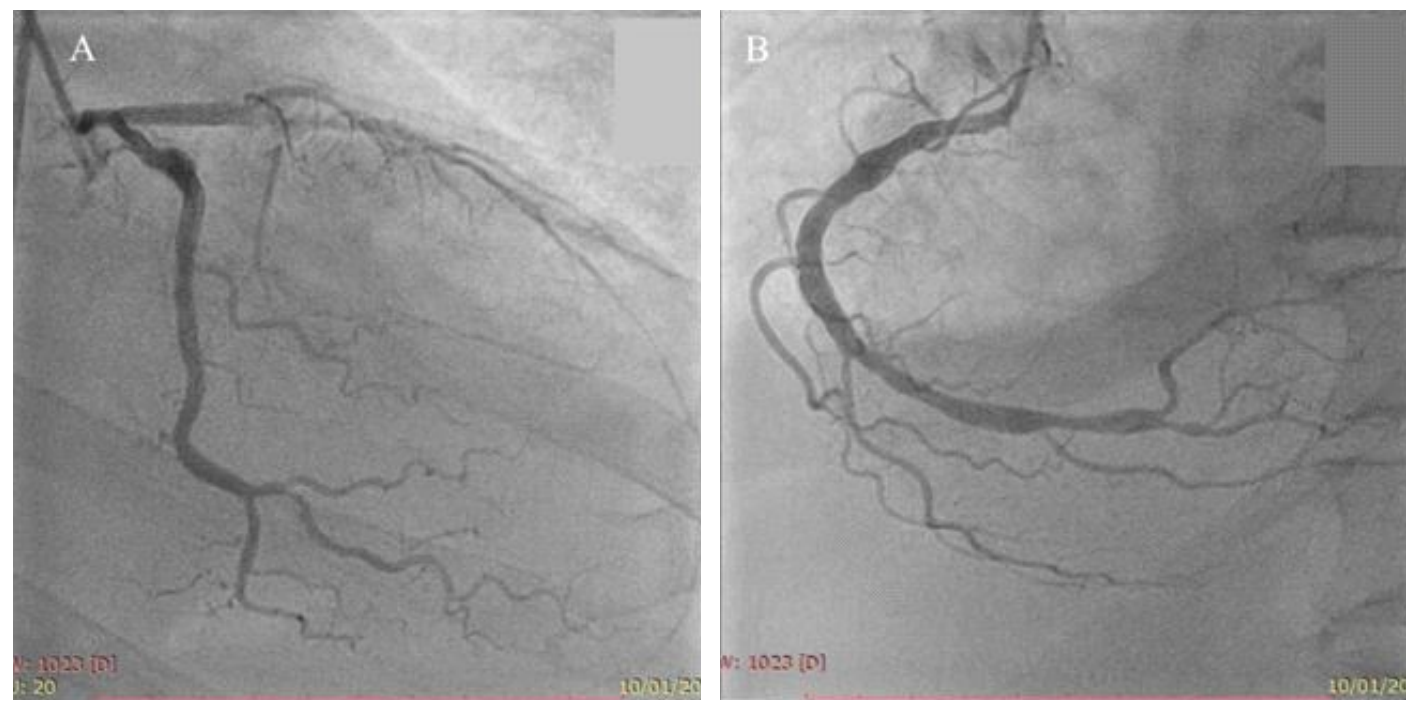

Gambar 3. Angiografi koroner menunujukkan (A) Stenosis $90 \%$ di mid dan $80 \%$ di distal LAD serta stenosis $40 \%$ di ostial-proximalLCX. (B) Stenosis 70-80\% di distal RCA

$2 \mathrm{mg}$.

Setelah dilakukan penegakan diagnosis dan stabilisasi awal, pasien di pindah ke ruang rawat Intensive Cardiac Care Unit (ICCU) RSDK.Selama di ICCU pasien mengalami hipotensi, hiperglikemia, peningkatan fungsi hepar serta imbalans elektrolit yang dapat dikoreksi secara medikamentosa selama perawatan. Dilakukan perawatan stabilisasi hemodinamik di ICCU selama 6 hari serta rencana tatalaksana penutupan VSR.
Angiografi koroner perkutan dilakukan dengan hasil stenosis $70-80 \%$ di distal right coronary artery (RCA), stenosis $90 \%$ di mid dan $80 \%$ di distal left anterior descending coronary artery (LAD) serta stenosis $40 \%$ di ostial-proximal left circumflex coronary artery (LCx) (Gambar 3), serta pada penyadapan jantung dengan hasil VSR Left to Right shunt High Flow Low Resistance. Dilakukan konferensi bedah jantung dengan tim bedah jantung kardiovaskular, anestesi, serta tenaga medis 


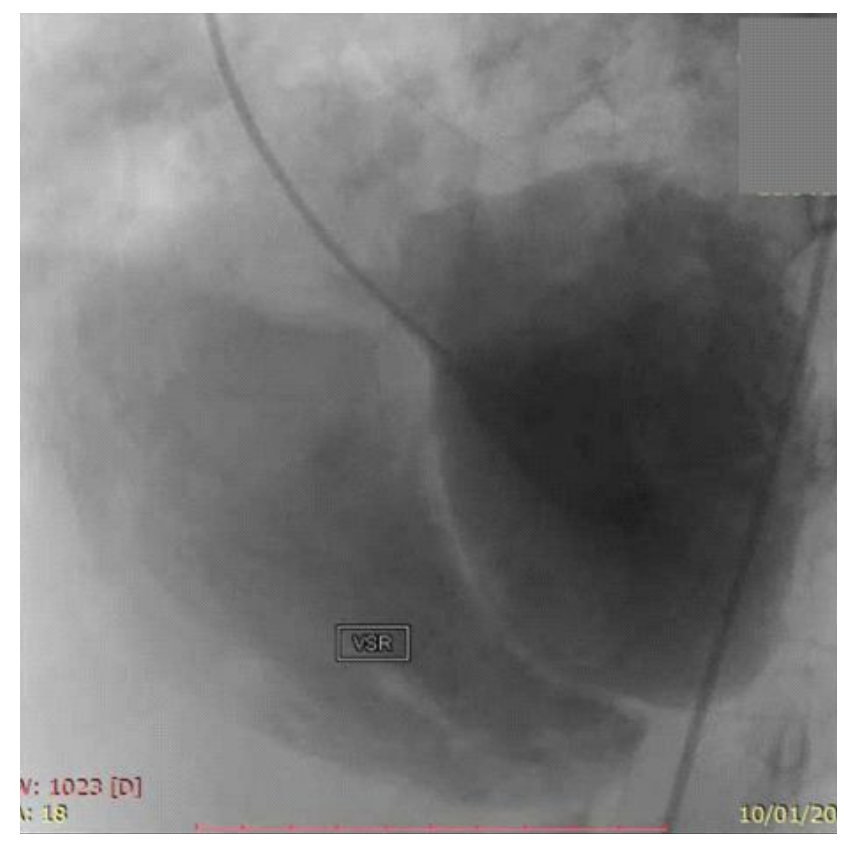

Gambar 4. Ventrikulografi kiri menunjukan VSR dengan pirau dari kiri ke kanan

ICCU didapatkan kesimpulan untuk bedah VSR dan BPAK setelah hemodinamik stabil.

\section{DISKUSI}

VSR merupakan komplikasi langka dan berat dari IMA yang hampir pada semua kasus terjadi peningkatan mortalitas tanpa intervensi bedah. Insidensi VSR 1-2\% ${ }^{1}$ pada era pre trombolisis dan menurun saat dimulainya era terapi trombolisis. ${ }^{2-5}$ VSR terjadi akibat infark penuh (transmural) dari septum ventrikel dan dapat terjadi pada setiap lokasi anatomi septum. Infark yang melibatkan left anterior descending coroner, dominan right coronary artery, atau dominan left circumflex artery dapat melibatkan seluruh cabang septal. VSR terjadi pada frekuensi yang sama pada infark anterior atau inferior. ${ }^{2}$ Infark anterior cenderung menyebabkan defek apikal, sedangkan infark inferior atau lateral cenderung menyebabkan defek pada perbatasan septal dan dinding posterior. Lalu terbentuklah shunt dari kiri ke kanan, dari darah yang beroksigen tinggi dari ventrikel kiri yang memiliki tekanan lebih tinggi ke ventrikel kanan yang bertekanan lebih rendah. Presentasi klinis dari mekanisme tersebut bervariasi mulai dari instabilitas hemodinamik, Infark, iskemia hingga volume overload dari ventrikel kanan. Instabilitas hemodinamik terjadi pada sebagian besar pasien dengan onset beberapa hariminggu.

Mekanisme terjadinya robekan septum melibatkan nekrosis koagulasi dari jaringan dengan infiltrasi neutrofilik yang menyebabkan terjadinya penipisan septum miokard. ${ }^{1}$ Proses subakut ini membutuhkan waktu 3-5 hari, yang menjadi acuan waktu dari terjadinya VSR pada literatur bedah terdahulu. Robekan terjadi pada 24 jam pertama sejak presentasi infark miokard lebih sering disebabkan oleh diseksi dari hematoma atau perdarahan intramural pada miokard. Hal ini terjadi akibat shear stress fisik pada perbatasan zona infark dengan hiperkontraksi miokard segmen yang jauh. Secara klinis hal ini sering terjadi pada infark inferior dengan VSR pada septum basal inferior yang berbatasan dengan mid septum hiperdinamik yang diperdarahi oleh LAD. VSR dapat pula terjadi secara bersamaan dengan komplikasi mekanik yang lain seperti aneurisma ventrikel, free wall rupture maupun papillary muscle rupture.

Becker dan Mantgem ${ }^{7}$ mengklasifikasikan kejadian patologis dari VSR menjadi tiga tipe. Tipe pertama yaitu robekan yang terjadi secara spontan, slit like tears dan berhubungan dengan infark akut (24 jam). Tipe kedua ditunjukkan dengan erosi pada infark miokard dan secara klinis menunjukan presentasi subakut. Tipe ketiga menunjukan rupture yang konkomitan dengan aneurisma dengan penipisan yang signifikan lalu terjadi ruptur yang secara klinis terjadi pada infark yang lebih lama.

Pada kasus ini VSR terjadi akibat IMA-EST Anterior pada onset lanjut sejak 5 minggu yang lalu yang tidak dilakukan tindakan revaskularisasi baik fibrinolitik maupun intervensi koroner perkutan. Kemudian muncul gejala sesak napas 2 minggu setelahnya yang menandakan suatu gejala gagal jantung dengan penurunan fungsi kontraksi dan kemungkinan terjadinya komplikasi mekanik berupa VSR. 


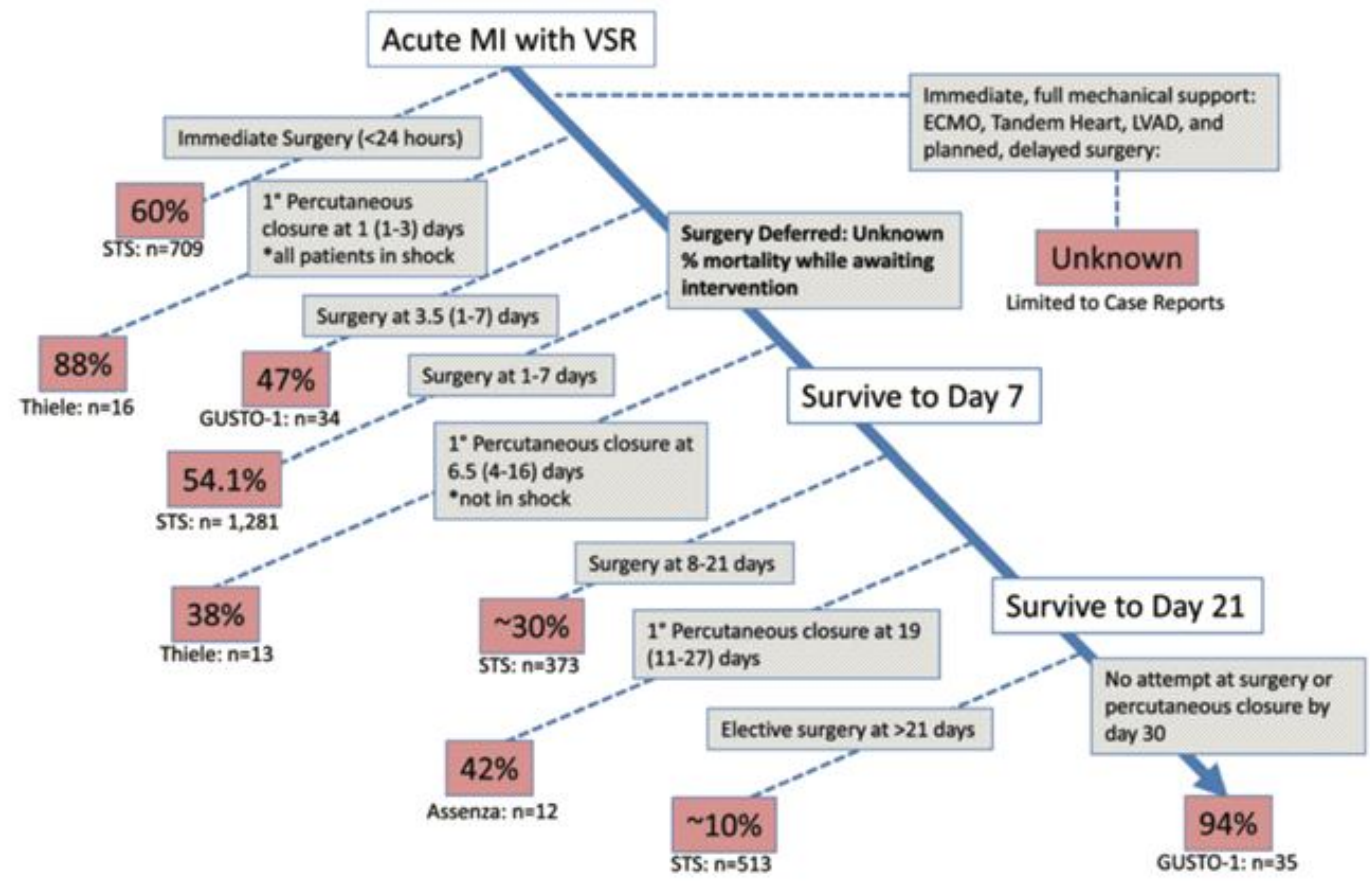

Gambar 5. Angka mortalitas 30 hari pada VSR dengan tatakelola bedah segera atau pada waktu penundaan tindakan intervensi. Angka mortalitas berkurang seiring dengan waktu yang meningkat dari diagnosa VSR hingga intervensi, akibat miokard yang lebih stabil dan juga bias kesintasan. ${ }^{6}$

Pemerisaan fisik pada pasien IMA sangat penting sebelum dilakukan IKP Primer. Semua pasien IMA dengan gangguan hemodinamik harus dengan segera dilakukan pemeriksaan auskultasi jantung untuk mendengaar adakah bising sistolik, harsh di dareah precordium atau apeks, meraba adakah thrill meskipun terkadang sulit ditemukan pada low ouput state. Pemeriksaan fisik lainya yaitu terjadinya peningkatan aliran pada ventrikel kanan dengan terdengarnya P2 yang meningkat, gallop S3 atau regurgitasi tricuspid.

Secara umum, diagnosis VSR dapat ditegakkan dengan pemeriksaan echocardiography trans torakal (TTE), yang menunjukan adanya defek pada septum ventrikel secara 2D dan terdapatnya aliran pada septum menggunakan colour doppler. Pada pasien dengan gambaran TTE yang kurang baik akibat ventilasi mekanik atau obesitas dapat dipertimbangkan untuk dilakukan Transesophageal Echocardiography. Ventrikulografi kiri dengan projeksi Left Anterior Oblique (LAO) pada pasien dengan VSR menunjukan shunting dari LV ke RV. Saturasi oksigen vena juga akan meningkat pada pemeriksaan kateterisasi jantung yang merefleksikan terjadinya shunting dari kiri ke kanan.

Pada kasus ini diagnosis VSR ditegakkan saat perawatan di IGD dengan presentasi klinis berupa gagal jantung akut dengan edema paru, dan hipertensi emergency. Oksigenasi, penurunan afterload dengan menggunakan nitrogliserine intravena dan penurunan preload dengan menggunakan diuretika fursemide intravena mampu memperbaiki kondisi gagal jantung akut pasien. Pemeriksaan fisik dan Ekokardiografi selama di IGD dilakukan menunjukan hasil pasien dengan VSR diameter $10 \mathrm{~mm}$ pirau kiri ke kanan dengan penurunan fraksi ejeksi ventrikel kiri sebesar 39\% sehingga pemantauan hemodinamik dengan target penyesuaian terapi dilakukan secara berkelanjutan.

Antiplatelet, statin, Angiotensin Converting Enzime (ACE) Inhibitor, Mineralocorticoid Receptor Antagonist (MRA) tetap diberikan sebagai terapi standar pada IMA.Adapun untuk tatalaksana VSR pada IMA-EST yang optimal dengan bedah penutupan VSR dan BPAK. ${ }^{8}$

Pembedahan merupakan pilihan terapi definitif, namun tingkat mortalitas dini paska bedah merupakan tantangan tersendiri. Pada studi Society of Thoracic Surgeons Database (STS Database) dilakukan penelitian pada 2876 individu dengan usia $>18$ tahun yang menjalani operasi VSR paska infark miokard pada tahun 1999-2010. ${ }^{9}$ Rerata kematian bedah $42,9 \%$ yang merepresentasikan mortalitas tertinggi dari semua prosedur bedah jantung. Pasien yang tidak selamat pada 30 hari pertama memiliki faktor resiko usia tua, wanita, peningkatan serum kreatinin, dan komorbid (syok kardiogenik, penurunan LVEF, penyakit jantung 3 pembuluh koroner, atau kebutuhan IABP preoperative). Studi lain pada 68 pasien, $85 \%$ dilakukan operasi <48 jam setelah diagnosis VSR ditegakkan dilakukan penilaian luaran post operatif. ${ }^{10}$ Pada kelompok ini, 22 dari 63 pasien $(35 \%)$ masih terdapat 


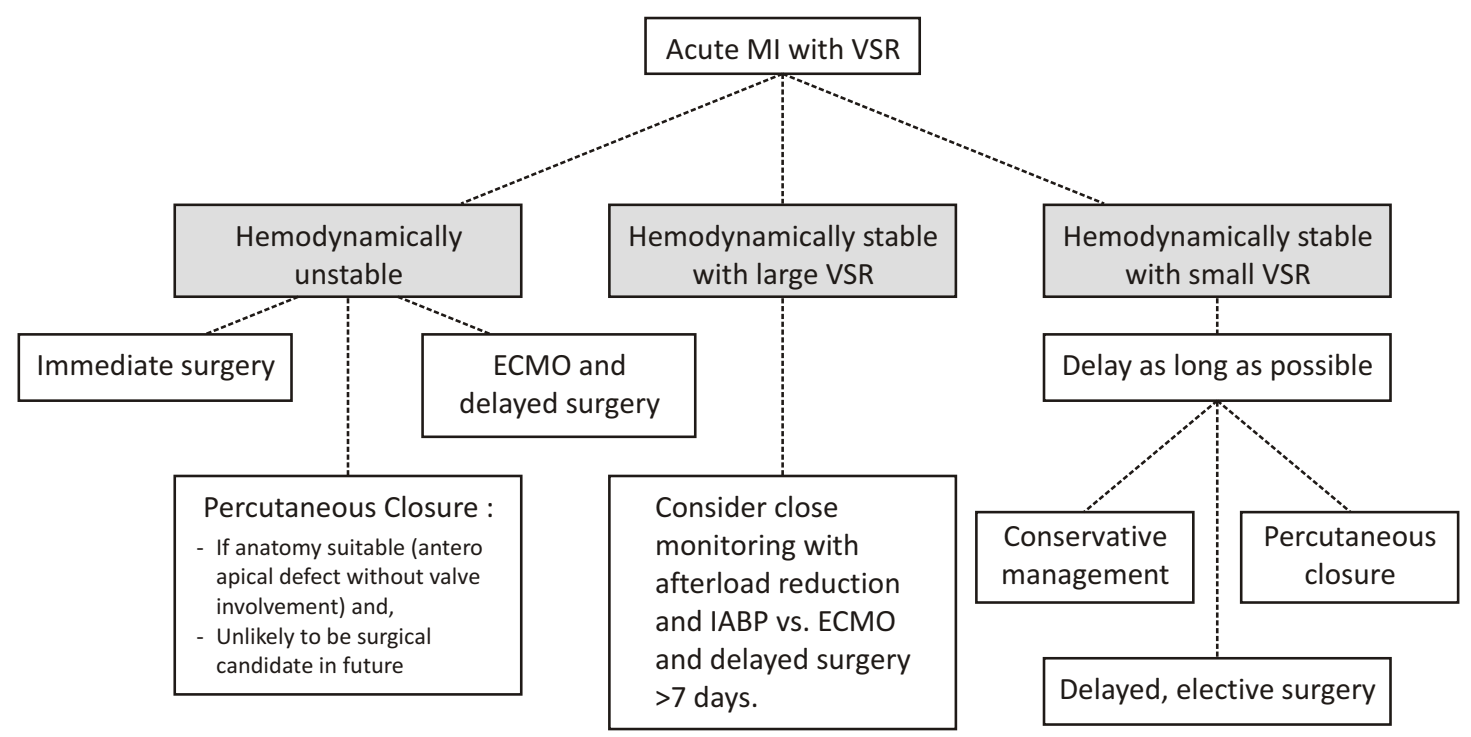

Gambar 6. Pendekatan multidisiplin untuk tatakelola VSR ${ }^{6}$

hubungan antar ventrikel dan selamat. Sebelas pasien menjalani operasi ulang akibat patch yang tidak sempurna dan terdapat instabilitas hemodinamik.

Mortalitas pasien pada studi STS bervariasi sesuai dengan waktu operasi. Pasien yang menjalani operasi pada 7 hari awal memiliki mortalitas $54,1 \%$ dibandingkan bila operasi ditunda diatas 7 hari $(18,4 \%)$. Mortalitas paling tinggi $(>60 \%)$ didapatkan pada pasien yang dilakukan operasi pada 24 jam pertama, yang sesuai dengan studi lain ${ }^{11}$ (Gambar5).

Luaran yang membaik pada penundaan operasi berhubungan dengan perubahan infark, peningkatan stabilitas jaringan miokard, dan juga akibat bias kesintasan dimana pada operasi dini dilakukan pada pasien dengan instabilitas hemodinamik dan gangguan sirkulasi. Hanya 886 dari 2876 pasien $(30,8 \%)$ dilakukan operasi diatas 7 hari yang mencerminkan hasil minor dari pasien yang selamat sampai dilakukan operasi elektif. Sesuai dengan GUSTO-I Trial yang menunjukkan mortalitas 30 hari sebesar $47 \%$ pada 34 pasien yang menjalani operasi segera (median 3,5 hari, 95\% CI, 1-7) dibanding mortalitas sebesar $94 \%$ pada 35 pasien tanpa operasi. ${ }^{3}$ Sehingga kedua studi diatas menunjukkan meskipun angka kematian pada pasien yang dilakukan operasi tinggi, angka kematian pada pasien tidak dilakukan operasi jauh lebih tinggi. Sehingga klinisi harus mempertimbangkan manfaat dan resiko pada tiap pasien dan pertimbangan kapan dilakukan tindakan operasi sebelum terjadi perburukan klinis lebih lanjut. Tatakelola VSR berdasar dari berbagai disiplin ilmu telah dibuat namun tiap individu memiliki pendekatan yang berbeda (Gambar 6).

Pasien ini muncul dengan presentasi gagal jantung, namun dengan hemodinamik stabil tanpa adanya syok kardiogenik yang sering menjadi pemberat dan meningkatkan mortalitas. Penundaan tindakan bedah tutup VSR pada defek yang kecil $(<15 \mathrm{~mm})$ merupakan pilihan dengan pertimbangan perbaikan stabilitas jaringan miokard sehingga meningkatkan tingkat keberhasilan bedah. Sehingga titik berat penatalaksanaan adalah dengan mempersiapkan kondisi hingga berhasil dilakukannya operasi dengan merupakan terapi yang tepat. Pengobatan dengan target oksigenasi yang baik, menurunkan aftterload dan diuretik yang cukup sambil mempertahankan perfusi jaringan dengan baik dapat meningkatkan angka kesintasan pasien.

\section{SIMPULAN}

Angka kematian pada IMA telah menurun pada tiga dekade terakhir, namun pasien pada subgrup VSR memiliki tingkat mortalitas yang masih tinggi. Pemeriksaan fisik yang baik disertai pemeriksaan penunjang seperti ekokardiografi pada pasien IMA terutama dengan hemodinamik tidak stabil, bermanfaat untuk penegakan diagnosis VSR. Tatalaksana pasien VSR dengan gagal jantung akut, bahkan syok kardiogenik yaitu dengan mengurangi pirau kiri ke kanan yang dilakukan dengan menurunkan afterload dan pemasangan IABP bila dibutuhkan. Penutupan VSR dengan bedah merupakan terapi definitif, walaupun pada kondisi seperti gagal jantung akut atau syok kardiogenik memerlukan pertimbangan klinis karena tingginya angka mortalitas. Sehingga klinisi harus mempertimbangkan manfaat dan resiko pada tiap pasien dan pertimbangan kapan dilakukan tindakan bedah sebelum terjadi perburukan klinis lebih lanjut. 
Pengelolaan VSR paska IMA memerlukan pendekatan multidispilin, oleh karena itu diperlukan koordinasi baik antar tim untuk mencapai luaran yang optimal.

\section{DAFTAR PUSTAKA}

1. BirnbaumY, Fishbein MC, Blanche C,Siegel RJ.Ventricular septal rupture after acute myocardial infarction. N Engl J Med 2002;347:1426-1432.

2. Moreyra AE, Huang MS, Wilson AC, Deng Y, Cosgrove NM, Kostis JB. Trends in incidence and mortality rates of ventricular septal rupture during acute myocardial infarction. Am J Cardiol 2010;106:1095-1100.

3. Crenshaw BS, Granger CB, Birnbaum Y, Pieper KS, Morris DC, Kleiman NS, Vahanian A, Califf RM, Topol EJ. Risk factors, angiographic patterns, and outcomes in patients with ventricular septal defect complicating acute myocardial infarction. GUSTO-I (Global Utilization of Streptokinase and TPA for Occluded Coronary Arteries) Trial Investigators. Circulation 2000;101:27-32.

4. Lopez-Sendon J, Gurfinkel EP, Lopezde Sa E, Agnelli G, Gore JM,Steg PG , Eagle KA, Cantador JR, Fitzgerald G, Granger CB. Factors related to heart rupture in acute coronary syndromes in the Global Registry of Acute Coronary Events. Eur Heart J 2010; 31:1449-1456.

5. French JK, Hellkamp AS, Armstrong PW, Cohen E, Kleiman NS, O'Connor CM, Holmes DR, Hochman JS, Granger CB, Mahaffey KW. Mechanical complications after percutaneous coronary intervention in ST-elevation myocardial infarction (from APEX-AMI). Am J Cardiol 2010;105:59-63.
6. Jones BM, Kapadia SR, Smedira NG, Robich N, Tuzcu EM,Menon V. Ventricular Septal Rupture Complicating Acute Myocardial Infarction : a contemporary review.Eur Heart J 2014;35:2060-2068.

7. Becker AE, van Mantgem JP. Cardiac tamponade. A study of 50 hearts. Eur J Cardiol 1975;3:349-358.

8. Ibanez, B., James, S., Agewall, S., et al. 2017 ESC Guidelines for the management of acute myocardial infarction in patients presenting with ST-segment elevation. Eur Heart J 2017; 00, $1-66$

9. Arnaoutakis GJ, Zhao Y, George TJ, Sciortino CM, McCarthy PM, Conte JV.Surgical repair of ventricular septal defect after myocardial infarction: outcomes from the Society of Thoracic Surgeons National Database. Ann Thoracic Surg 2012;94: 436443; discussion 443-444.

10. Fukushima S, Tesar PJ, Jalali H, Clarke AJ, Sharma H, Choudhary J, Bartlett H, Pohlner PG. Determinants of inhospital and long-term surgical outcomes after repair of postinfarction ventricular septal rupture. J Thoracic Cardiovasc Surg 2010; 140:59-65.

11. Papalexopoulou N, Young CP, Attia RQ. What is the best timing of surgery in patients with post-infarct ventricular septal rupture? Interactive Cardiovasc Thoracic Surg 2013;16:193-196. 